\title{
ERIFERNI GRADSKI TEKST
Ulično nazivlje i spomenici zagrebačke Dubrave u semiotičkoj perspektivi
}

\author{
Laura Šakaja \\ Geografski odsjek, Prirodoslovno-matematički fakultet \\ Sveučilišta u Zagrebu \\ Ivana Crljenko \\ Leksikografski zavod Miroslav Krleža, Zagreb
}

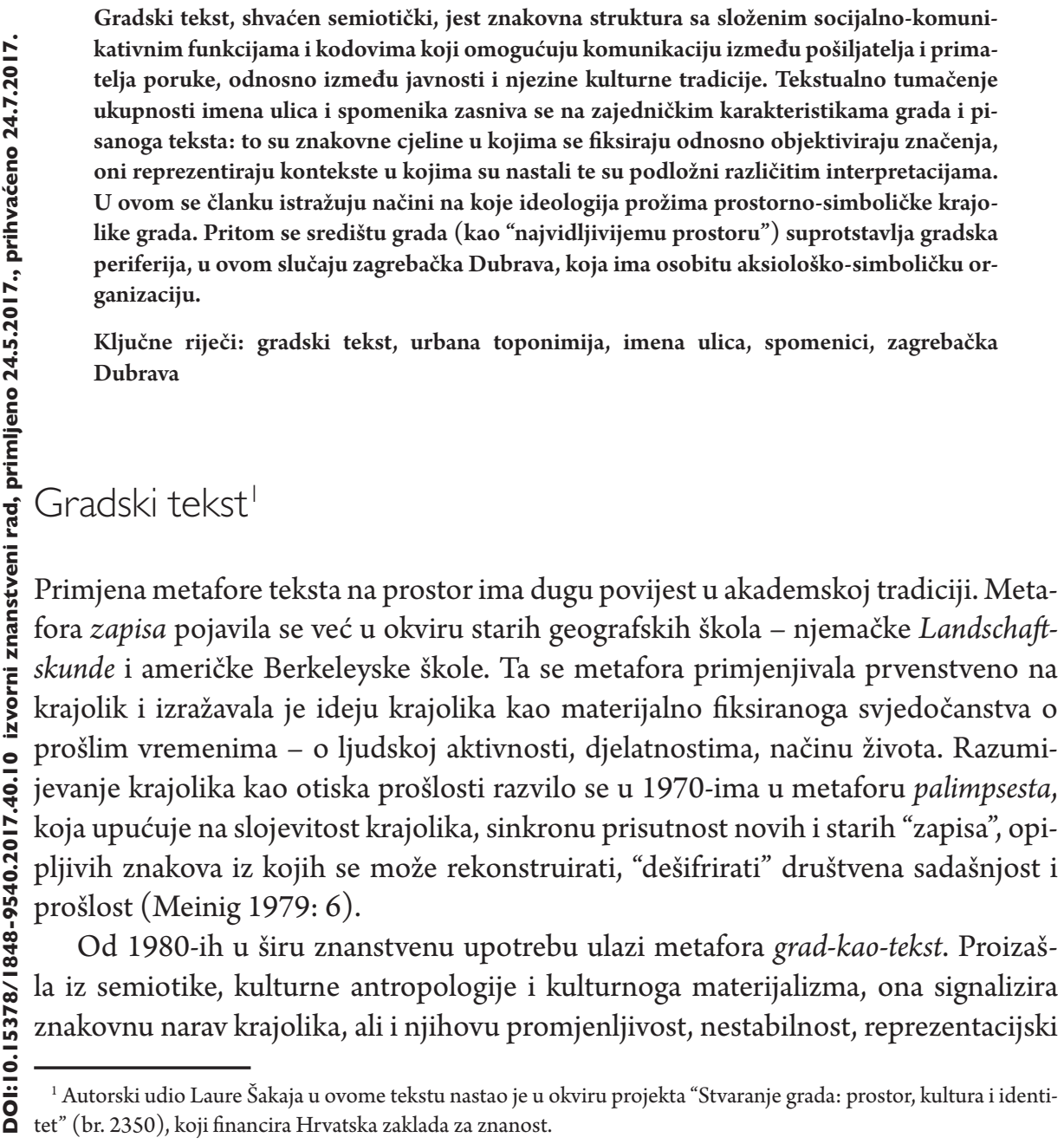


karakter, otvorenost različitim interpretacijama. Ta metafora implicira skrivene kodove krajolika, proizvodnju i "autorstvo" krajolika, njegovu ideologičnost (Duncan i Duncan 1988; Duncan 1990). Sintagma gradski tekst (city-text), koja je proistekla iz te metafore, razvila se posljednjih desetljeća u koristan istraživački alat za analizu simboličke infrastrukture grada kao materijalnoga očitovanja vladajućih društvenih diskursa. Upravo ćemo se na taj način koristiti izrazom gradski tekst i u ovome radu, a središnju temu istraživanja - imena ulica (odnosno hodonime) i spomenike tumačit ćemo kao bitne elemente gradskoga teksta.

Gradski tekst ovdje se razumije semiotički - kao znakovna struktura sa složenim socijalno-komunikativnim funkcijama, kao mehanizam s raznovrsnim kodovima. On sudjeluje u komunikaciji između pošiljatelja i primatelja poruke, između javnosti i kulturne tradicije. On upućuje na kulturni kontekst, i čita se u kulturnom kontekstu. Gradski tekst nastupa u ulozi posrednika koji pomaže "čitatelju" u orijentaciji unutar kulturnih konstrukcija. Kao prostorni zapis, gradski je tekst trajan. Istodobno, on je i promjenjiv: transformira već postojeće poruke i generira nove, rekodira se sukladno promijenjenim društvenim okolnostima (Lotman 1992).

Mogućnost tekstualnog tumačenja ukupnosti imena ulica i spomenika zasniva se na sljedećim zajedničkim karakteristikama grada i pisanoga teksta:

- to su znakovne cjeline,

- u njima se značenja objektiviraju, fiksiraju,

- oni reprezentiraju kontekste u kojima su nastali,

- oni su podložni različitim interpretacijama (v. Šakaja 2015: 237).

Sintagmu gradski tekst prvi su na sustav uličnih imena primijenili Kari Palonen (1993) i Maoz Azaryahu (1996), i to u kontekstu politika pamćenja. Palonen smatra imena ulica ključnom dimenzijom gradskoga teksta, a njihovo imenovanje normativnom procedurom koja propisuje granice prihvatljivoga i određuje odlike "dobrih imena". On tvrdi da nam čitanje imena ulica kao gradskoga teksta omogućuje da dobijemo brz uvid u povijest grada, a osobito u promjene političke klime (Palonen 1993: 104-105). Azaryahu tekst uličnoga nazivlja (ulične toponimije) smatra simboličkim izrazom moći, sredstvom simboličkoga utemeljenja uspostavljenoga poretka. Potencijal uličnoga nazivlja, s gledišta politike i moći, vidi u njegovoj sposobnosti da uvede autoriziranu verziju povijesti u obični okvir svakodnevnoga života.

U prvoj dekadi 21. stoljeća termin gradski tekst postao je jednim od temeljnih pojmova u radovima iz područja urbane toponimije. Emilia Palonen (2008) u svom radu o politikama krajolika u Budimpešti uključuje u pojam gradski tekst, uz urbanu toponimiju, i gradske spomenike. Upravo na taj način, na primjeru uličnoga nazivlja i spomenika, proučit ćemo ovdje tekst zagrebačke Dubrave, ostavljajući pri tome izvan fokusa druge dimenzije simboličkoga gradskoga krajolika (arhitekturu, morfologiju, strukturu grada), na koje se pojam gradski tekst također, nesumnjivo, može odnositi.

Posljednjih godina objavljen je niz radova u kojima se spomenici tematiziraju kao utjelovljenje službenoga pamćenja (Sidaway i Mayell 2007), kao dio procesa artikulacije nacionalnoga identiteta (Johnson 2004: 321) ili, općenito, kao aspekt simbolič- 
koga krajolika grada (npr. Johnson 1995; Foote 1997; Atkinson i Cosgrove 1998; Till 1999; Azaryahu 2003; Dwyer 2004; Hook 2005; Azaryahu i Foote 2008; Alderman 2010).

Tema ulične toponimije također je dospjela u fokus mnoštva radova (npr. Mac Aodha 1989; Yeoh 1992, 1996; Myers 1995; Azaryahu 1996; Berg i Kearns 1996; Withers 2000; Alderman 2000, 2002, 2003; Azaryahu i Kook 2002; Pinchevski i Torgovnik 2002; Rose-Redwood 2008; Vuolteenaho i Berg 2009; Rose-Redwood, Alderman i Azaryahu 2010; Rose-Redwood, Alderman i Azaryahu 2017). Unutar korpusa znanstvene produkcije o simboličkim krajolicima grada posebnu skupinu čine radovi koji se bave urbanom toponimijom i spomeničkom infrastrukturom postsocijalističkih gradova (Azaryahu 1997; Light, Nicolae i Suditu 2002; Light 2004; Forest, Johnson i Till 2004; Robinson i Pobrić 2006; Czepczyński 2008; Palonen 2008; Light i Young 2014). Uključenost Hrvatske u procese postsocijalističke transformacije simboličkih krajolika dokumentirana je u nizu znanstvenih radova (npr. Rihtman-Auguštin 2000; Begonja 2006; Grgin 2007; Marjanović 2007; Crljenko 2008, 2011; Stanić, Šakaja i Slavuj 2009; Šakaja i Stanić 2011; Mataija 2014; Mirošević i Borzić 2014; Radović 2014, 2016; Oroz i Škrbić Alempijević 2015; Vretenar i Krajina 2016; Mirošević 2016). Kako vidimo iz tih radova, napuštanje socijalističke ideologije te izgradnja novih postsocijalističkih identiteta bili su popraćeni revalorizacijom predsocijalističke i socijalističke prošlosti i nasljeđa, a među postupcima i mehanizmima koji su karakterizirali novu interpretaciju povijesti bila su masovna uklanjanja spomenika te brojna preimenovanja ulica i trgova.

$\mathrm{U}$ ovome ćemo radu problematici gradskoga teksta pristupiti s prostornoga motrišta. Naglasak na ideološkoj prožetosti simboličkih krajolika grada neizbježno stavlja u prvi plan središnje dijelove grada. Upravo centralne ulice, kao "najvidljiviji prostor”, postaju ideološki orijentiri. Zagreb je izvrstan primjer toga. Upravo su zagrebački trgovi Donjega grada, kao ključna mjesta gradske topografije, najdosljednije pratili promjene društvenih i političkih prilika tijekom različitih smjena režima (Rihtman-Auguštin 2000; Stanić, Šakaja i Slavuj 2009). U ovome se radu postavljaju pitanja: Kako su se promjene simboličkoga krajolika odvijale u područjima udaljenima od gradskoga centra? Kakav je periferni gradski tekst i kako se on mijenja? Što pripada periferiji grada u sustavu u kojem se statusna hijerarhija osoba i događaja transponira u urbani prostor? Ako se osobe i događaji visokoga aksiološkoga statusa pozicioniraju u centar, koje se osobe i događaji smještaju na periferiju prostorne i statusne hijerarhije?

Tim je pitanjima u znanstvenoj literaturi posvećeno vrlo malo pozornosti. Prvi je s promišljanjem geografskih aspekata urbane toponimije krenuo Alderman (2003), upozorivši na važnost razine vidljivosti ulica (lokacije, dužine, mjesta u uličnoj hijerarhiji) u politikama preimenovanja. Najzanimljivijim se u kontekstu našega istraživanja čini rad “Street Names in Bucharest, 1990-1997” Duncana Lighta (2004), koji je, analizirajući promjene ulica u Bukureštu, primijetio razliku u rekonfiguraciji simboličkoga krajolika između gradskoga centra i periferije. Karakteristično brisanje tragova socijalizma, naime, mnogo se dosljednije provodilo u centralnim, "vid- 
ljivim", dijelovima Bukurešta, dok je njegova periferija bila izvan osnovnoga fokusa politike preimenovanja.

Perspektiva ovoga rada također je geografska. Na primjeru zagrebačke Dubrave želimo prikazati kako je njezin periferni položaj utjecao na formiranje i promjene njezina simboličkoga krajolika.

\section{Periferni tekst dubravskoga simboličkoga krajolika}

Dubrava je do intenzivnijega naseljavanja u 1950-ima imala obilježja predgrađa. Dijelovi današnje Dubrave već su 1947. pripojeni gradu Zagrebu (mjesni narodni odbor Zagrebačka Dubrava). Godine 1949. Zagrebu su pripojeni i dijelovi mjesnih narodnih odbora Granešina, Čulinečka Dubrava i Resnički Gaj. Time je Dubrava postala sastavnim dijelom grada. Danas ona čini rubno, periferno gradsko područje na istoku Zagreba. Zeleni pojas između Dubrave i kompaktno izgrađenoga gradskoga područja Zagreba pruža se od najsjevernijih dijelova medvedničkoga prigorja do njezinih najjužnijih dijelova - samo se u dijelu Donje Dubrave koji se nastavlja na Vukomerec taj pojas gubi. Takva fizionomska odvojenost Dubrave zelenom zonom odredila je specifičnost njezina razvoja kao fizički zasebnoga gradskoga područja. U odnosu na središnje kompaktno izgrađene dijelove grada Dubrava se formirala kao gradski areal perifernih obilježja (Crljenko 2011).

Prema unutargradskom ustrojstvu iz 1999. godine na području Dubrave formirane su dvije od sedamnaest gradskih četvrti Zagreba - Gornja i Donja Dubrava. Danas Gornja Dubrava ima 4026,57 ha i oko 62000 stanovnika, a Donja Dubrava 1080,99 ha i oko 36000 stanovnika. ${ }^{2}$ Na krajolike Dubrave uvelike je utjecao povijesni razvoj njezine morfološke strukture, odnosno morfogeneza (v. Crljenko 2012a). Taj je razvoj tekao spontano u najranijoj povijesti Dubrave, kada su se formirala prva dubravska sela na obroncima Medvednice te rijetka sela i zaseoci južno od današnje glavne prometne arterije, Ulice Dubrava, dok se o njezinoj morfogenezi nakon Drugoga svjetskoga rata, a posebice nakon Domovinskoga rata, uz rijetke iznimke manjeg prostornog obuhvata planske izgradnje, može govoriti kao o stihijskom, neplanskom, nekontroliranom, "divljem" razvoju. Upravo je nekontrolirani razvoj morfološke strukture glavni čimbenik kako današnjeg izgleda Dubrave tako i slike Dubrave u prostornoj imaginaciji Zagrepčana. S Dubravom se, naime, asocira "kaos", "nered", "divljina”. O njoj se govori kao o "Divljem zapadu", "slamu”, u nekim dijelovima i o "maloj Palestini” (Crljenko 2011: 90).

Brza i neplanska izgradnja pojedinih predjela Dubrave remetila je uobičajeni proces uličnog imenovanja. $\mathrm{O}$ tome, među ostalim, svjedoči velik broj ulica koje sadrže brojke u svojem imenu. U Dubravi je, na primjer, čak trinaest Novoselskih odvojaka (Novoselski odvojak I., Novoselski odvojak II. itd.), osam Trnava (Trnava I., Trnava II.

\footnotetext{
${ }^{2}$ Prema podacima Popisa stanovništva 2011.
} 
itd.), pet Celovečkih odvojaka, tri Ljutomerska, tri Senjska itd. ${ }^{3}$ Većina takvih ulica smještena je u područjima neplanske izgradnje gdje se izgrađeni prostor očito širio brže od planskoga imenovanja ulica.

\section{Pučka imena i patronimi}

Odražavanje perifernosti na morfologiju prepoznajemo $u$, karakterističnoj za Dubravu, kombinaciji planskih naselja uređene infrastrukture i starih naselja seoskoga tipa s ostacima drvene arhitekture. Područje novijega razvoja, koji započinje 1930-ih godina, supostoji s područjem starih sela sjeverno, južno i istočno od kompaktno izgrađenoga dijela Dubrave. Nasuprot relativno gusto naseljenim područjima u unutarnjim zonama Dubrave, ${ }^{4}$ područja na njezinim južnim i sjevernim rubovima gotovo su nenaseljena ili vrlo rijetko naseljena. Na područjima mjesnih odbora Dankovec, Novoselec, Branovec-Jalševec, Čučerje, koji su još prije tridesetak godina bili prigradska sela, i danas živi tek 2 - 5 stanovnika po hektaru, a Resnički gaj gotovo je nenaseljen. ${ }^{5}$

Periferni položaj Dubrave vrlo je očit u imenima njezinih ulica. To u prvom redu vidimo iz ulica povezanih s lokalnom toponimijom: zemljištima, selima, zaseocima relativno nedavno uključenima u gradsko područje. Za razliku od središnjih dijelova Zagreba gdje je stara pučka ulična toponimija već tijekom prvoga službenog sustavnog imenovanja ulica 1878. godine bila uglavnom promijenjena u nazivlje višeg registra, u dubravskim su imenima ulica mnoga stara pučka lokalna imena sačuvana dosad. Najviše takvih hodonima možemo uočiti u području nekadašnjih sela Gornje Dubrave. U mjesnom odboru Branovec-Jalševec nalazi se, na primjer, Branovečka cesta, Svibovečki put, Jalševačka cesta, u Čučerju nalazimo ulice Selščak, Trstenik, Vinišče, Baboščica, u Dankovcu ulice Pavlinščak, Lazina, Gumerec, u Granešinskim Novakima ulice Lešče, Kosainščak, Zakiščak i dr.

Indikativnu skupinu čine patronimi. Kao i drugdje, u Dubravi su se, u područjima srednjovjekovnog naseljavanja, predjeli na kojima su nekad živjele veće i istaknutije obitelji ili su ih posjedovale imućne obiteljske dinastije nazivali tim obiteljskim imenima (prezimenima ili obiteljskim nadimcima). U dubravskim su se ulicama, osobito ulicama sjevernoga dijela Gornje Dubrave, do danas sačuvali takvi patronimi. ${ }^{6}$ Prijašnje društvene/obiteljske zajednice očituju se u brojnim imenima ulica motiviranima patronimima lokalnih plemića ili kaptolskih kmetova: Mudifaji,

\footnotetext{
${ }^{3}$ Današnja imena ulica u članku preuzeta su sa Službenih stranica Grada Zagreba i Google Mapsa.

${ }^{4} \mathrm{~S}$ više od 50, ponegdje i više od 100 stan/ha, poput Novog Retkovca (112,47 stan/ha) (Popis stanovništva 2011. i Službene stranice Grada Zagreba).

${ }^{5}$ Dankovec 4,36 stan/ha, Novoselec 3,85 stan/ha, Branovec-Jalševec 2,76 stan/ha, Čučerje 2,45 stan/ha, Resnički gaj 1,06 stan/ha (Popis stanovništva 2011. i Službene stranice Grada Zagreba).

${ }^{6}$ Treba primijetiti da je zastupljenost lokalne toponimske, a posebno patronimične (hod)onomastike tipična ne samo za Gornju Dubravu nego i za druge dijelove podsljemenske zone grada, što na simboličkoj razini reflektira specifični zagrebački urbano-ruralni kontinuum. Zahvaljujemo anonimnom recenzentu što nam je na to skrenuo pozornost.
} 
Naglići, Prevende, Buhini, Cekovići, Micudaji, Šuškovići, Majpruzi, Orešići, Lobori, Žugci, Cuglini, Đurini, Ilići, Huzeki i dr.

Registru lokalnog identiteta pripadaju i ulice kojih su imena povezana s lokalnim plemenskim bratstvima i naseljima nazvanima po njima (Oporovec, Branovec, Čugovec, Dankovec, Miroševec), tj. ulice kojih su imena motivirana imenima navedenih naselja. Tako nekadašnju prisutnost plemenskog bratstva Opora ili Obora neizravno obilježava čak šest ulica. ${ }^{7}$ Bratstvu Bratona duguju svoje ime Branovečka cesta i Branovečina. Imena nekih od ulica izvedena su iz imena pojedinih članova bratstva Bratona: Čugovečki put je povezan s izvjesnim Čutkom, članom bratstva, Dankovečka ulica - $s$ bratom Donkom, Miroševečina, Miroševečka cesta, Miroševečki brijeg, Miroševečki gaj - s bratom Miroslavom (Junaković 1978).

U Donjoj Dubravi hodonimi motivirani lokalnim toponimima su rjeđi. Među rijetkim su iznimkama oni izvedeni iz imena starih sela u Donjoj Dubravi (Čulincu, Resniku, Retkovcu i Trnavi), Čulinečka cesta, Čulinečki put, Resnički gaj, Resnički put, I. - VII. Retkovec, I. - VIII. Trnava. Štoviše, ovdje ni jedna ulica ne nosi ime po patronimima lokalnih plemića ili kaptolskih kmetova, a samo one motivirane imenom naselja Čulinec i Retkovec obilježavaju postojanje plemićkih bratstava i njihovih istaknutih članova - brata Cehne, odnosno Retka. Razlog tome možemo potražiti u prirodnim i društvenim čimbenicima. Naime, zbog rebrastoga reljefa južnih padina Medvednice s proširenim dolinama u prigorju, širenje Dubrave intenzivnije se odvijalo prema sjeveru nego prema jugu, pa je upravo u sjevernim dijelovima nastala većina starih dubravskih sela (Globarević 1974; Crljenko 2011). Donja je Dubrava, s iznimkom malenih sela, sve do 19. stoljeća bila gotovo nenaseljen kraj u posjedu Kaptola. Kada je započela parcelacija kaptolskoga posjeda, ondje se ona počela provoditi kasnije i sporijom dinamikom nego u Gornjoj Dubravi, pa su se prve kuće na novoformiranim donjodubravskim parcelama (zajedno s ulicama) izgradile tek 1930-ih.

\section{Migracije i geografija u uličnom nazivlju}

Razvoj naselja Dubrava počinje u međuratnome razdoblju, u 1930-im godinama. Izgradnjom tramvajske pruge 1942. godine, koja je spaja sa središtem grada, Dubrava postaje sastavnim dijelom grada. Razvoj industrije u Zagrebu u međuratnom, a osobito u poratnom razdoblju uvjetovao je potrebu za radnom snagom i rezultirao snažnim priljevom migranata iz drugih područja Hrvatske i Jugoslavije. Doseljavalo se pretežito seosko i radničko stanovništvo koje je bilo privučeno mogućnošću individualne izgradnje na neizgrađenim parcelama na rubu velikoga grada, jeftinim dubravskim zemljištem i nižim troškovima izgradnje zbog lako dostupnoga građevinskog materijala i vode te povoljnom cijenom stanova u planski izgrađenim novim stambenim

\footnotetext{
${ }^{7}$ Oporovečka ulica, Oporovečki dol, Oporovečki Majdaki, Oporovečki odvojak, Oporovečki Omajek, Oporovečki vinogradi.
} 
blokovima. Vrijeme od druge polovice 1940-ih do druge polovice 1960-ih možemo izdvojiti kao razdoblje najjačih migracija u Dubravu (Crljenko 2011: 109-110; Crljenko 2012b: 297). ${ }^{8}$

Godine 1981. u ukupnom stanovništvu Dubrave, uslijed migracija, čak je oko dvije trećine činilo doseljeno stanovništvo (Švob, Brčić i Podgorelec 1998: 17). Istraživanje provedeno 1970-ih (Globarević 1974) pokazalo je da je većina doseljenika u poslijeratnom razdoblju došla iz Središnje Hrvatske (75,3\%), i to iz Hrvatskoga zagorja, Bilogorske Podravine, susjednih zagrebačkih općina (Dugo Selo, Samobor, Zaprešić, Velika Gorica), Varaždinske Podravine i Međimurja. Znatan broj migranata doselio se i iz Primorske Hrvatske (12,5\%) te Istočne Hrvatske (10,4\%). Dolazili su i migranti s područja bivše Jugoslavije, a izvorišta poslijeratnog vala tih doseljenika indirektno možemo iščitati iz brojnosti srpske $(4,8 \%)$ i bošnjačke $(2,0 \%)$ manjine u ukupnom stanovništvu Dubrave godine 1991. (Švob, Brčić i Podgorelec 1998: 17).

Naseljavanje Dubrave kao perifernoga dijela grada koji je nudio zaposlenje i napredak očitovalo se $\mathrm{u}$ osebujnosti sustava njezina uličnoga nazivlja. Potreba za brzim imenovanjem ulica u uvjetima ubrzanog rasta stanovnika, neplanske izgradnje i nastanka novih ulica dovela je do bujanja imena ulica po naseljima Hrvatske i bivše Jugoslavije. ${ }^{9}$ Mnogi su hodonimi reproducirali imena hrvatskih sela, manjih gradića ili dijelova manjih gradića, ${ }^{10}$ vrlo rijetko većih ili srednjih gradova. ${ }^{11}$ Pri tome je u imenima ulica koje su nazvane po nekom hrvatskom toponimu, kao i u ishodištima migracija, prevladavala Središnja i Istočna Hrvatska (Crljenko 2011: 333). Migrantski mozaik Dubrave tako je bio transponiran u imena njenih ulica.

Imena ulica koja su odgovarala imenima naselja drugih jugoslavenskih saveznih republika bila su, u pravilu, grupirana u cjeline. Tako je ekspanzija jugoslavenskih doseljenika na planski izgrađenom užem području Dubrave ${ }^{12}$ (Ladović 1960) sredinom 1950-ih godina popraćena formiranjem osebujnoga sustava uličnih imena na tom području. $U$ tom su se sustavu ulice $s$ imenima ideoloških konotacija ${ }^{13}$ križale s ulicama kojih su imena reproducirala industrijsku geografiju bivše Jugoslavije. $\mathrm{Na}$ planu grada iz 1959. godine vidimo da su ulice u tom dijelu Dubrave mahom nazvane po industrijskim, pretežito rudarskim, naseljima raznih dijelova Jugoslavije:

\footnotetext{
${ }^{8}$ U razdoblju 1946. - 1960. prosječan godišnji porast broja doseljenih u Dubravu bio je 563,5, što je u odnosu na razdoblje 1941. - 1945. povećanje od čak 376,3\%. I sljedeće razdoblje (1961. - 1970.) donijelo je znatan godišnji porast doseljenih (234,3\% u odnosu na prethodno razdoblje). Sedamdesetih godina 20. stoljeća broj doseljenih na godišnjoj se razini smanjio pa je početkom 1980 -ih iznosio $78,6 \%$ onoga iz prethodnog razdoblja. Znatnije povećanje ponovno je uslijedilo u razdoblju 1991. - 1995., kada je prosječan godišnji porast broja doseljenih iznosio 2294,5, što je u odnosu na razdoblje 1986. - 1990. povećanje od 269,4\% (prema posebno obrađenim podacima popisa stanovništva, DZS).

${ }^{9}$ Pri tome se očito i ovdje, kao i u drugim perifernim dijelovima Zagreba, implementirao princip imenovanja naslijeđen još iz razdoblja prije Drugoga svjetskoga rata - da za ulice s nižom gradnjom treba uzimati nazive jugoslavenskih pokrajina i gradova (Šimunović 1970).

${ }^{10}$ Na primjer, Hlebinska, Legradska, Lipovljanska, Nuštarska, Okućanska.

${ }^{11}$ Na primjer, Osječka, Vukovarska.

${ }^{12}$ Danas mjesni odbor Dubrava-središte.

${ }^{13}$ Ulica prosinačkih žrtava, Ulica Druge armije i Ulica Posavskog odreda (Zagreb - popis ulica i plan grada, 1965).
} 
$\mathrm{BiH},{ }^{14}$ Srbije, ${ }^{15}$ Slovenije, ${ }^{16}$ Kosova, ${ }^{17}$ što je očito trebalo simbolizirati spoj i slogu radničke klase jugoslavenskih naroda.

Koncentraciju jugoslavenskih toponima vidimo i u nekim neplanski izgrađenim dijelovima Dubrave. Na primjer, doseljavanje migranata iz bivše države u vrijeme “divlje" gradnje Trnave od početka 1960-ih preslikano je u geografiju trnavske ulične toponimije - s imenima naselja iz Srbije, ${ }^{18}$ Crne Gore ${ }^{19}$ i BiH. ${ }^{20} \mathrm{U}$ cjelini, prisutnost jugoslavenske toponimije u hodonimima Dubrave odgovarala je dubravskoj narodnosnoj strukturi: među imenima ulica jugoslavenskoga podrijetla prije raspada Jugoslavije u Dubravi je bilo najviše onih izvedenih iz imena bosanskohercegovačkih, srbijanskih i crnogorskih naselja.

\section{Ideologija u registru lokalnoga}

Imena ulica i spomenici aktivni su alati i mediji artikulacije lokalnih i nacionalnih politika i ideologijskih pozicija. U gradskome tekstu urbane toponimije i spomeničke infrastrukture materijaliziraju i simboliziraju politički i ideološki identitet. Vidljivost gradskoga krajolika čini imena ulica i spomenike vrlo pogodnim alatom legitimizacije svjetonazora.

Gradski tekst Zagreba, kao važnoga ideološkoga orijentira, kontinuirano je komunicirao i posredovao službeni svjetonazor tijekom promjena režima od austrougarskoga razdoblja do danas (v. Stanić, Šakaja i Slavuj 2009). Punokrvno uključivanje Dubrave u taj proces možemo smjestiti u vrijeme poslije Drugoga svjetskoga rata, kada se Dubrava ubrzano izgrađuje, urbanizira i širi. To je bilo razdoblje kada su se u svim dijelovima Jugoslavije, pa tako i u Zagrebu, sustavno mijenjala imena ulica i trgova. I Dubrava se uključuje u te procese, imenovanjem ulica po partizanskim odredima, divizijama, istaknutim događajima i datumima iz razdoblja NOB-a. ${ }^{21}$ Deseci ulica dobivaju imena po palim borcima NOB-a ili žrtvama ustaške odmazde. ${ }^{22}$ Obilježavanje događaja iz Drugoga svjetskoga rata i antifašističke borbe odvija se i izgradnjom spomenika te ugradnjom spomen-ploča. Prema podacima Saveza antifašističkih boraca Hrvatske do 1990. godine u Dubravi je bilo ukupno trideset šest spomen-obilježja: dvanaest spomenika, jedno spomen-poprsje, tri memorijalna mu-

\footnotetext{
${ }^{14}$ Banovička, Kakanjska, Prijedorska, Teslička, Zavidovička, Vareška, Tuzlanska, Ljubijska.

${ }^{15}$ Niška, Kostolačka, Borska.

${ }^{16}$ Trbovljanska, Idrijska, Velenjska.

${ }^{17}$ Trepčanska.

${ }^{18}$ Bagrdanski put, Apatinska ulica, Ćuprijski put, Dobropoljska ulica, Kalenički put, Paraćinski put, Kriveljski put, Jagodinska ulica.

${ }^{19}$ Baošićki put, Hercegnovski put, Lepetanski put, Kumborski put, Seljanovski put, Đenovički put, Perašćanski put, Zelenički put.

${ }^{20}$ Kladuška ulica.

${ }^{21}$ Ulica Posavskog odreda, Prosinačkih žrtava, Druge armije, Pete zemaljske konferencije, Pionirska, XXI. srpske proleterske divizije, I. udarne partizanske grupe, Dvadeset devetog novembra, III ofenzive, Trg prosinačkih žrtava, Trg I. zagrebačkog odreda, Aleja pionira (Zagreb. Plan grada, 1990).

22 Štajnerova, Grgaševićeva, Kuzmiakova, Češnjakova, Delgalova i mnoštvo drugih.
} 
zeja, jedno spomen-obilježje i devetnaest spomen-ploča, koja su obilježavala pojedine događaje iz NOB-a (Hrženjak 2002).

Analizirajući ideološko označavanje prostora grada u poratno vrijeme možemo zapaziti dva fenomena koja razlikuju Dubravu od centralnih dijelova grada:

1. Širenje grada i nastanak novih ulica omogućili su ekstenzivnu ideologizaciju prostora, odnosno opsežno imenovanje ulica po fenomenima i osobama koji za politiku nisu bili od prvorazredne, centralne važnosti. O tome, na primjer, govori činjenica da je mnogim osobama po kojima su tada nazvane dubravske ulice danas vrlo teško rekonstruirati identitet.

2. Ideologija se prvenstveno očitovala preko lokalnih fenomena. Mnoštvo dubravskih ulica i spomenika nastalih u poratno vrijeme referiralo se na lokalne događaje i lokalne stanovnike. Po konferenciji koja je 1940. godine održana u Dubravi (v. Ivanuša 1981), na primjer, nazvana je Ulica Pete zemaljske konferencije. Upravo u jednoj dubravskoj kući je osnovan Prvi zagrebački partizanski odred, koji je dobio svoj trg u Dubravi. Niz spomenika toga doba izgrađen je u slavu borcima i žrtvama rata iz dubravskoga Čučerja, Branovca, Oporovca, Granešinskog Novoselca i Dubrave u cjelini. Paradigmatski primjer povezivanja ideološkoga i lokalnoga čini obilježavanje događaja koji se odvio u Dubravi - masovnoga vješanja talaca u prosincu 1943. godine. Vješanje je bilo odmazda za diverziju partizana, a upravo su u Dubravi instalirana improvizirana vješala na kojima je vršeno pogubljenje (Dobrila-Pepo 1986). Po prosinačkim je žrtvama nakon rata imenovana glavna dubravska prometna arterija i park. Na mjestu pogubljenja podignut je Spomenik prosinačkim žrtvama (skulptora Dušana Džamonje), jedno od važnih djela nefigurativne jugoslavenske umjetnosti (Kožarić 2007: 164).

Ukratko, za razliku od centra grada, kamo su dospijevali fenomeni koji su u tadašnjoj verziji čitanja povijesti bili od središnjeg povijesnog značaja, ${ }^{23}$ Dubravi je u prostorno-hijerarhijskoj raspodjeli vrijednosti pripala uloga sukladna njezinoj perifernoj poziciji u gradu. Ideologija se ovdje očitovala u registru lokalnoga.

\section{Promjene gradskog teksta u postsocijalističkome razdoblju}

Azaryahu (2012) definira promjene imena ulica kao "rituale revolucije" koji, u skladu s različitim interesima i prioritetima, prenose preko krajolika uličnih imena obavijest o velikim političkim pomacima i ideološkoj preorijentaciji društva. Preimenovanja ulica dio su nastojanja institucionalizacije političkih ili revolucionarnih promjena, odnosno relativno izravan i brz način javnoga pokazivanja da je došlo do promjene režima i promjene smjera (Light 2004).

Slična je i uloga spomenika. U svojem radu "Cast in Stone: Monuments, Geography and Nationalism” Nuala Johnson (1995) naziva spomenike važnim središtima oko kojih se artikuliraju lokalne i nacionalne političke i kulturne pozicije.

\footnotetext{
${ }^{23} \operatorname{Trg}$ Republike, Prilaz JNA, Trg bratstva i jedinstva, Lenjinov trg, Ulica 8. maja, Trg maršala Tita i dr.
} 
Kulturni krajolik, kako ga je slikovito definirao David Lowenthal, “jedan je od najefikasnijih alata pamćenja” (Lowethal 1979: 104). Informacija ugrađena u ime ulice ili u oblik spomenika pretvara se u znak, ona se materijalizira i vizualizira, postaje dostupna, trajna, transformira se u razumljiv oblik. Gradski je tekst stoga mnemonički alat, nositelj pamćenja.

Gradski tekst je dio kulture, a ona stalno uključuje i isključuje određene tekstove, stvara nove, a uništava neke druge tekstove (Lotman 1993: 331). Poticani smo da pamtimo određene činjenice, a zaboravljamo neke druge. Postoje i činjenice koje jednostavno nestaju u mnoštvu informacija sve većega opsega (Legg 2007: 458; Lachmann 2002; Eco 1988). Određene pojave i događaji materijaliziraju se u krajoliku semiotičkom fiksacijom, a drugi nisu fiksirani u krajoliku. Krajolik stoga podržava ne samo pamćenje nego i zaborav. Kao posrednici i nositelji sjećanja i zaborava, uključivanja i isključivanja baštine, ulična toponimija i spomenici instrumenti su politika baštine.

Promjena gradskoga teksta Zagreba odgovarala je općim tendencijama simboličke tranzicije postsocijalističkih gradova Europe. Ponovno ispisivanje grada prvenstveno se odnosilo na promjenu gradske toponimije. U razdoblju od 1990. do 2007. godine Odbor za imenovanje naselja, ulica i trgova - radno tijelo pri Gradskoj skupštini Zagreba ${ }^{24}$ - preimenovao je čak 474 ulice, većinu u prvim godinama tranzicije (Stanić, Šakaja i Slavuj 2009).

Sa spomenicima je slučaj nešto drugačiji. Centralno sankcioniranih promjena u spomeničkoj mreži bilo je znatno manje: u prvih deset godina tranzicije službeno je u Zagrebu odobreno premještanje samo dvije statue na manje vidljivo (istaknuto) mjesto te uklanjanje četiri biste i osam spomen-ploča (premještene u muzejske fondove).${ }^{25}$ Brojne biste i spomen-obilježja koji su se u pravilu nalazili u krugu škola, vrtića ili mjesnih zajednica (što su nosili ime odgovarajućega heroja) uklanjani su ${ }^{26}$ bez službenoga odobrenja gradske uprave. Sa stambenih su zgrada sami stanari uklanjali ploče što su najčešće informirale o nekom događaju ${ }^{27}$ koji se zbio u zgradi, ili o životu i djelovanju nekoga tada istaknutoga pojedinca (Ugarković i Očak 1979).

U Dubravi je gradski tekst također bio podvrgnut sličnim promjenama. U nastavku ćemo analizirati osnovne tendencije tih promjena.

\footnotetext{
${ }^{24}$ Treba primijetiti da su slična povjerenstva, bilo na gradskoj, bilo na općinskoj razini, djelovala u Zagrebu od prvoga zakonskog imenovanja zagrebačkih ulica provedenoga 1878. godine. Analiza načina formiranja tih tijela, a isto tako analiza profila aktera koji su donosili odluke o imenovanjima te okolnosti i konteksta njihova biranja, svakako bi mogla u znatnoj mjeri pridonijeti razumijevanju institucionalnoga transponiranja političkih procesa u simboličku strukturu grada. No to je predmet posebnoga istraživanja.

${ }^{25}$ Podaci Gradskoga ureda za graditeljstvo, stambene i komunalne poslove, promet i veze, 2000.

${ }^{26}$ Dokument: Obavijest o stanju spomenika i spomen obilježja na području PU Trešnjevka, 1992.

${ }^{27}$ Sastanku mjesnog komiteta Komunističke partije, osnutku ogranka KP, hapšenju sekretara KP i sl.
} 
Rekonfiguracija sjećanja na prošlost

U Dubravi je od 1990. do kraja 2016. godine preimenovano sto osamnaest ulica i trgova. ${ }^{28}$ Među najbrojnijim kategorijama hodonima koji su promijenjeni bili su oni vezani za Drugi svjetski rat, komunistički i antifašistički pokret (Slika 1). Sva ideološki obojena imena ulica bila su zamijenjena, najčešće politički neutralnim imenima ili onima koja odražavaju hrvatski identitet (npr. hrvatskim toponimima ili imenima osoba iz hrvatske i bosanskohercegovačke povijesti, primjerice imenima hrvatskih i hercegovačkih svećenika). Stoga, gledano u cjelini, možemo govoriti o zaokretu uličnoga nazivlja prema svojevrsnoj deideologizaciji i depolitizaciji gradskoga teksta. ${ }^{29}$

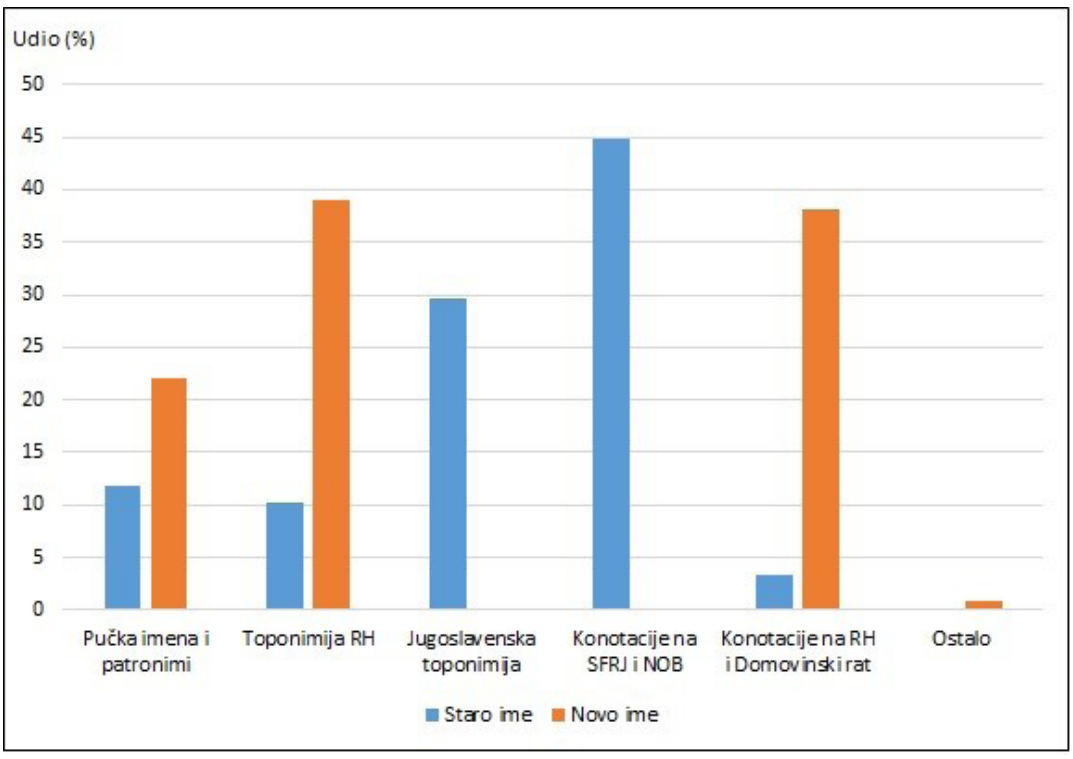

Slika I. Struktura imena preimenovanih ulica prije 1990. (stara imena) i poslije 1990. (nova imena) Izvor: Popis preimenovanih ulica i trgova, 2007.; Službeni glasnik Grada Zagreba 2007. - 2016.; Službene stranice Grada Zagreba; izradila: Ivana Crljenko, 2017. godine

Ipak je i među novim imenima ulica bilo političko-ideoloških. Pojavljivanje Ulice Hrvatskoga proljeća i Ulice Križnoga puta jasno je indiciralo nove naglaske u službenom čitanju povijesti.

Promjene su se dogodile i u spomeničkom segmentu simboličkog čitanja povijesti. Postavljeno je spomen-poprsje Anti Starčeviću. Istovremeno, oštećeno je, pre-

\footnotetext{
${ }^{28}$ Prema podacima popisa preimenovanih ulica i trgova Ureda za katastar i geodetske poslove grada Zagreba (2007) i Službenim glasnicima Grada Zagreba (2001. - 2016.).

${ }^{29} \mathrm{O}$ tome govori i činjenica da je tijekom preimenovanja ulica nakon 1991. godine po hrvatskim znanstvenicima i kulturnjacima bilo imenovano oko dvadeset pet ulica.
} 
namijenjeno ili uklonjeno osamnaest spomen-obilježja iz bivšeg režima, uglavnom spomen-ploča. ${ }^{30}$ Iako su najmarkantniji spomenički objekti sačuvani, postsocijalistička rekonfiguracija društvenoga sjećanja uzrokovala je određene njihove modifikacije i prilagodbu, u skladu s novim mjestom događaja ili osobe u novoj hijerarhiji panteona. Modifikacija spomenika događala se na dva načina: prostornim pomicanjem i resemiotizacijom (Šakaja i Stanić 2011).

\section{a) Pomicanje spomenika}

Spomenik prosinačkim žrtvama koji je stajao na humku u središtu parka istoga imena spušten je s uzvisine i pomaknut u dubinu parka, čime je bila postignuta njegova "prostorna degradacija”, odnosno manja prostorna vidljivost (Slika 2). Slično tome je "degradiran" Spomenik palim borcima NOR-a u Čučerju - premještanjem s glavnoga čučerskoga trga prema rubu obližnjega groblja, dakle sa središnje pozicije u naselju na rubno i manje vidljivo mjesto (Slika 3).

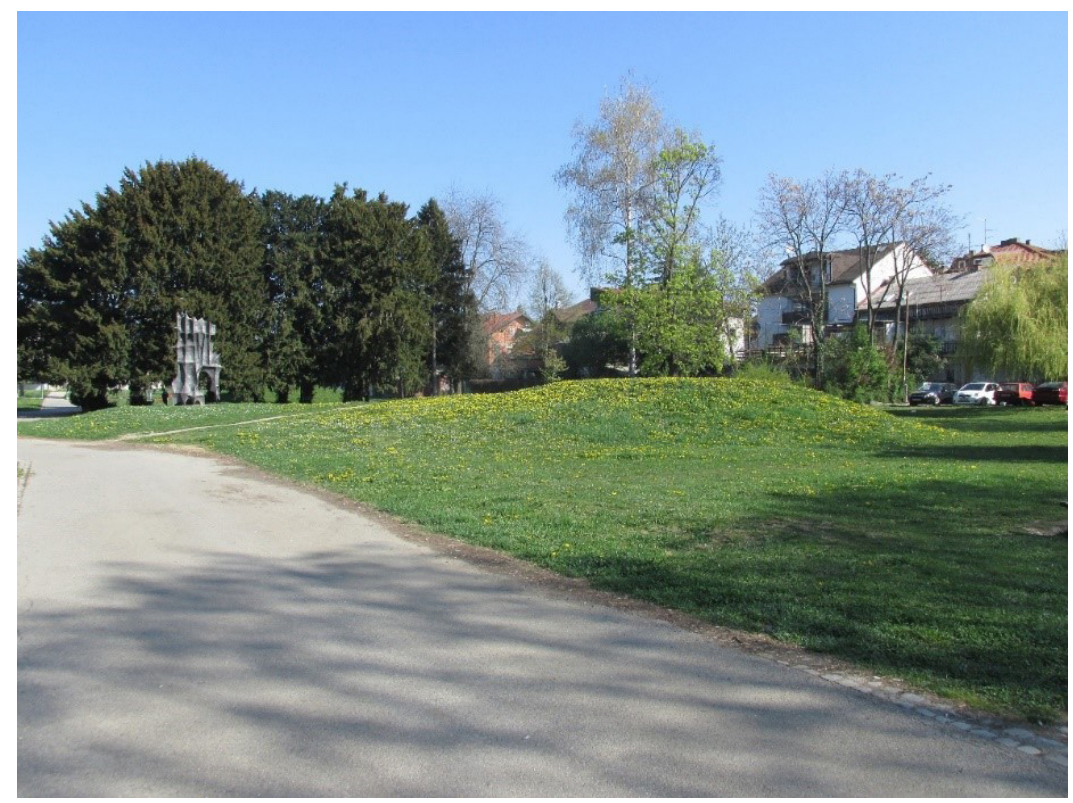

Slika 2. Spomenik prosinačkim žrtvama i uzvisina (desno) na kojoj je nekad stajao. Fotografirala: Laura Šakaja, 2017. godine

\footnotetext{
${ }^{30}$ Prema: Hrženjak (2002) i dokumentaciji Gradskog zavoda za zaštitu spomenika kulture i prirode.
} 


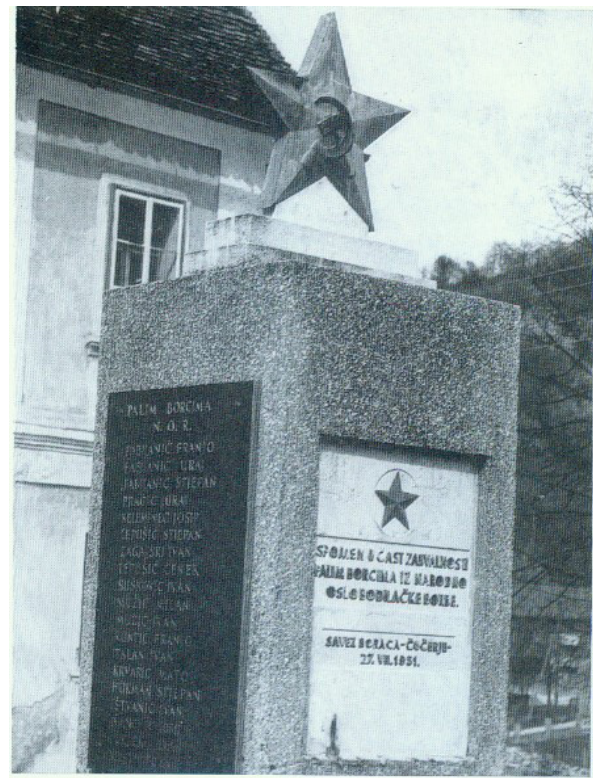

Slika 3. (A) Spomenik palim borcima NOR-a u Čučerju na čučerskom trgu 1979. godine

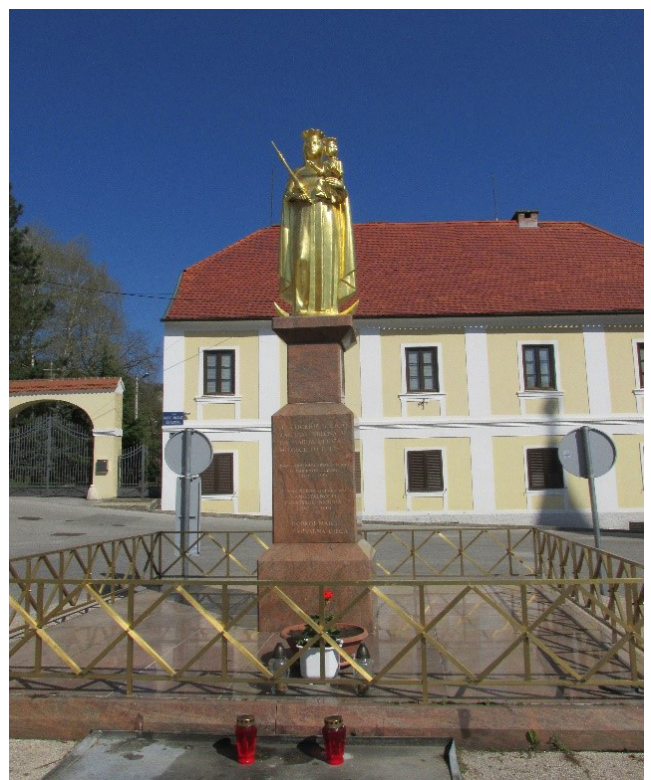

Slika 3. (B) Spomenik Bogorodica na njegovu mjestu od 199I. godine

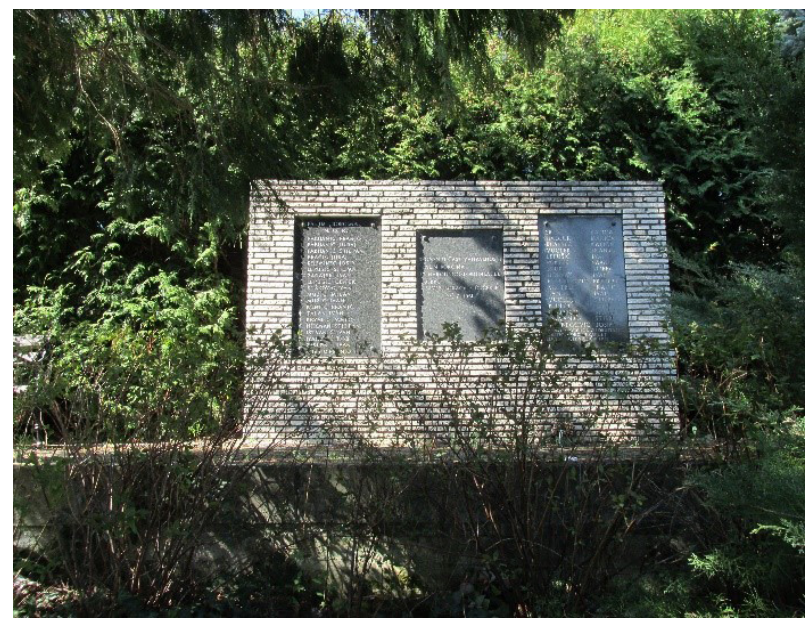

Slika 3. (C) Spomen-ploče sa Spomenika palim borcima NOR-a u Čučerju, danas na ulazu u mjesno groblje

Izvor: Ugarković i Očak 1979; fotografirala: Laura Šakaja, 2017. godine 

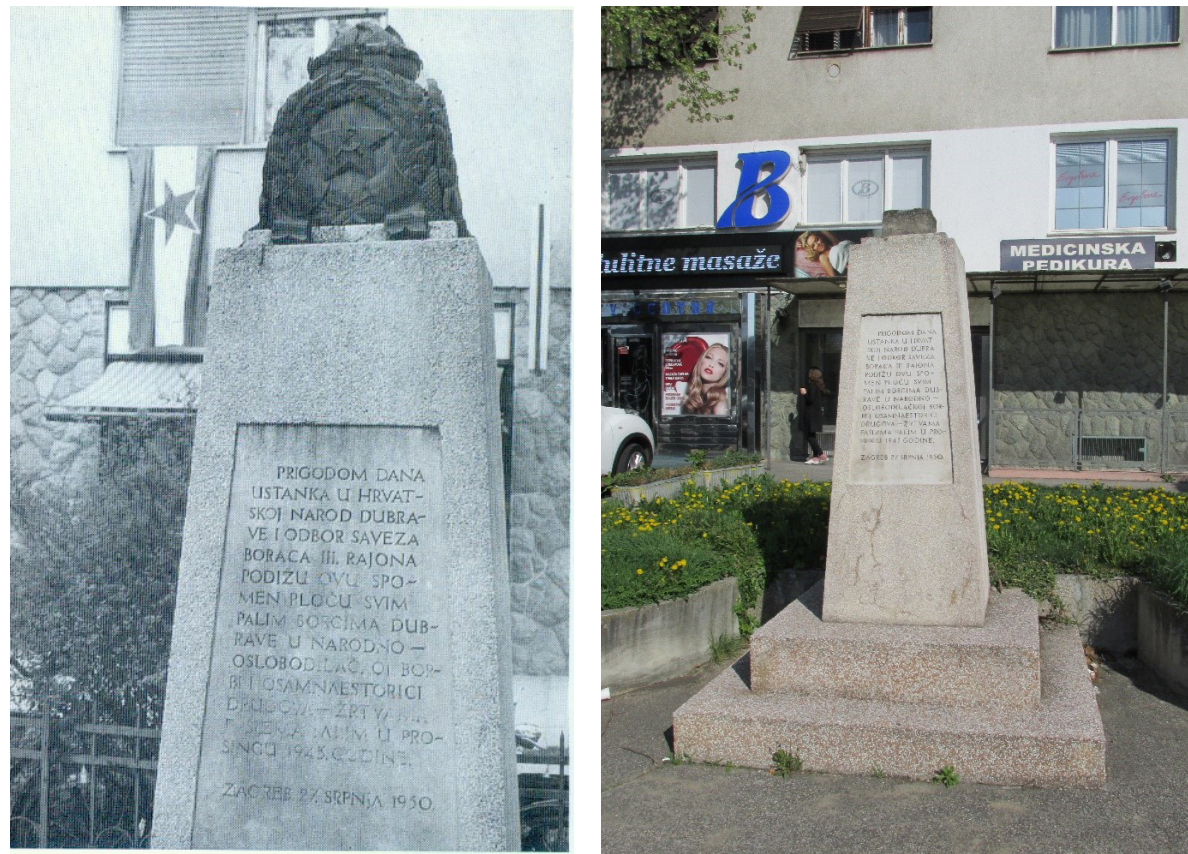

Slika 4. Spomenik palim borcima i žrtvama fašizma Dubrave sa zvijezdom na vrhu 1979. godine (A) i bez zvijezde 2017. godine (B) Izvor: Ugarković i Očak 1979; fotografirala: Laura Šakaja, 2017. godine

\section{b) Resemiotizacija spomenika}

Nizu spomenika u Dubravi bila je skinuta zvijezda (Slika 4). ${ }^{31}$ Kao što je poznato, antifašistička baština Hrvatske praktično je neodvojiva od komunističke. Skidanjem zvijezde kao simbola komunizma nepoznati su počinitelji simbolički odvojili ta dva fenomena: antifašizam od komunizma, ono što zahtijeva današnji normativni diskurs od onoga što je ostalo izvan njega, ono što "treba pamtiti” od onoga što se "mora prepustiti zaboravu”. Resemiotizacijom, odnosno simboličkom redukcijom, spomenici su na nov način dopušteni u sferu baštine.

Resemiotizacija spomenika postizala se i "simboličkom nadgradnjom" (Foote 1997; Dwyer 2004). U Novoselcu, pored spomenika s natpisom PALIM BORCIMA NOR-A ŽRTVAMA FAŠISTIČKOG TERORA godine 2012. postavljen je križ s tekstom: U SLAVU SPASITELJA ISUSA KRISTA I NEBESKOJ MAJCI NA TRAJAN SPOMEN ČASNIM PRECIMA KOJI NA OVOME MJESTU 1935. KRIŽ PODIGOŠE. Simbolička je nadgradnja, kao što vidimo, ukinula jednosmjernost diskursa te ga je proširila drugačijim vrijednosnim kodovima.

\footnotetext{
${ }^{31}$ Spomenik palim borcima i žrtvama fašizma Dubrave, Spomenik palim borcima i žrtvama fašizma Granešinskog Novoselca, Spomen-ploča palim borcima NOR-a iz Čučerja.
} 
Još jedan zanimljiv primjer simboličke nadgradnje odnosi se na spomenički kompleks koji je, zajedno s Tvornicom željezničkih vozila Gredelj, bio prebačen u Dubravu iz Trnja (Slika 5). Bista Janka Gredelja postavljena je 1959. godine. Dvije godine kasnije ona postaje dio spomen-obilježja podignutoga Gredeljevim radnicima poginulima u NOB-u. Godine 1997. spomen-obilježju dodan je novi spomenik - poginulim braniteljima, zaposlenicima TŽV Gredelj u Domovinskom ratu. Sva tri djela čine jedinstven kompleks koji sadrži natpise nastale u raznim vremenima i političkim okolnostima: JANKO GREDELJ NARODNI HEROJ 1916-1941; SPOMEN PALIM DRUGOVIMA 1941-1945; ZAPOSLENICIMA POGINULIM U DOMOVINSKOM RATU 1991-1995. ZA HRVATSKU DRŽAVU.

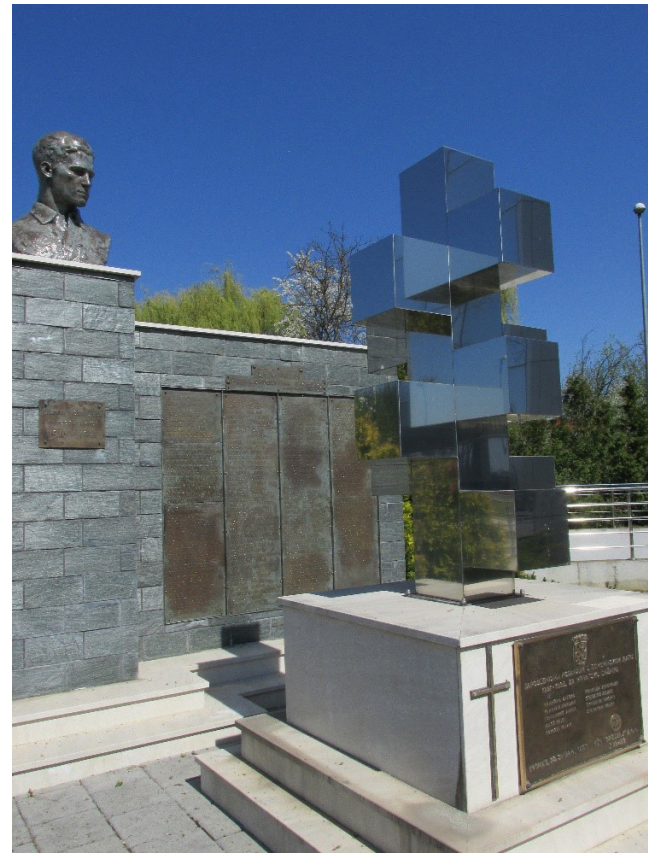

Slika 5. Spomenički kompleks ispred TŽV Gredelj. Fotografirala: Laura Šakaja, 2017. godine

Za razliku od središnjih zagrebačkih ulica i trgova gdje su se, u skladu s europskom tradicijom, novim preimenovanjima ulica obilježavali događaji i osobe koji pripadaju davnoj prošlosti, periferni položaj Dubrave omogućio je da se u njoj oda počast onome što pripada sferi suvremenosti, odnosno nedavnoj prošlosti. Širenje grada, formiranje novih ulica omogućuje ekstenzivnu ugradnju novih sadržaja. U terminima Aristotelove retorike mogli bismo reći da se u dubravskom gradskom tekstu primjenjivala ne samo sudbena nego i epideiktička retorika. ${ }^{32}$ Upravo u epideiktičku retoriku možemo svrstati obilježavanje sjećanja na Domovinski rat. Po dubravskim

\footnotetext{
${ }^{32}$ Sudbenom se retorikom, prema Aristotelu, tretiraju (prosuđuju, ocjenjuju) događaji prošlosti. Za razliku od nje, epideiktičkom retorikom ističu se kvalitete, vrline i značenje suvremenika (Aristotel 1989; Palonen 1993). To je retorika pohvale, svečanog uzdizanja hrabrosti, pravednosti, mudrosti i drugih vrlina.
} 
braniteljima u Domovinskom ratu nazvani su $\operatorname{trg}^{33}$ i dva parka. ${ }^{34}$ Izgrađen je i spomenik poginulim braniteljima Dubrave. Usto su u razdoblju od 2002. do 2016. godine po braniteljima poginulima u Domovinskom ratu nazvane dvadeset tri ulice, uglavnom u rubnim dijelovima Staroga Retkovca, Trnave i Čulinca (Slika 6). Većina tih ulica nosi imena pripadnika 145. brigade, članovi koje su bili stanovnici Dubrave.

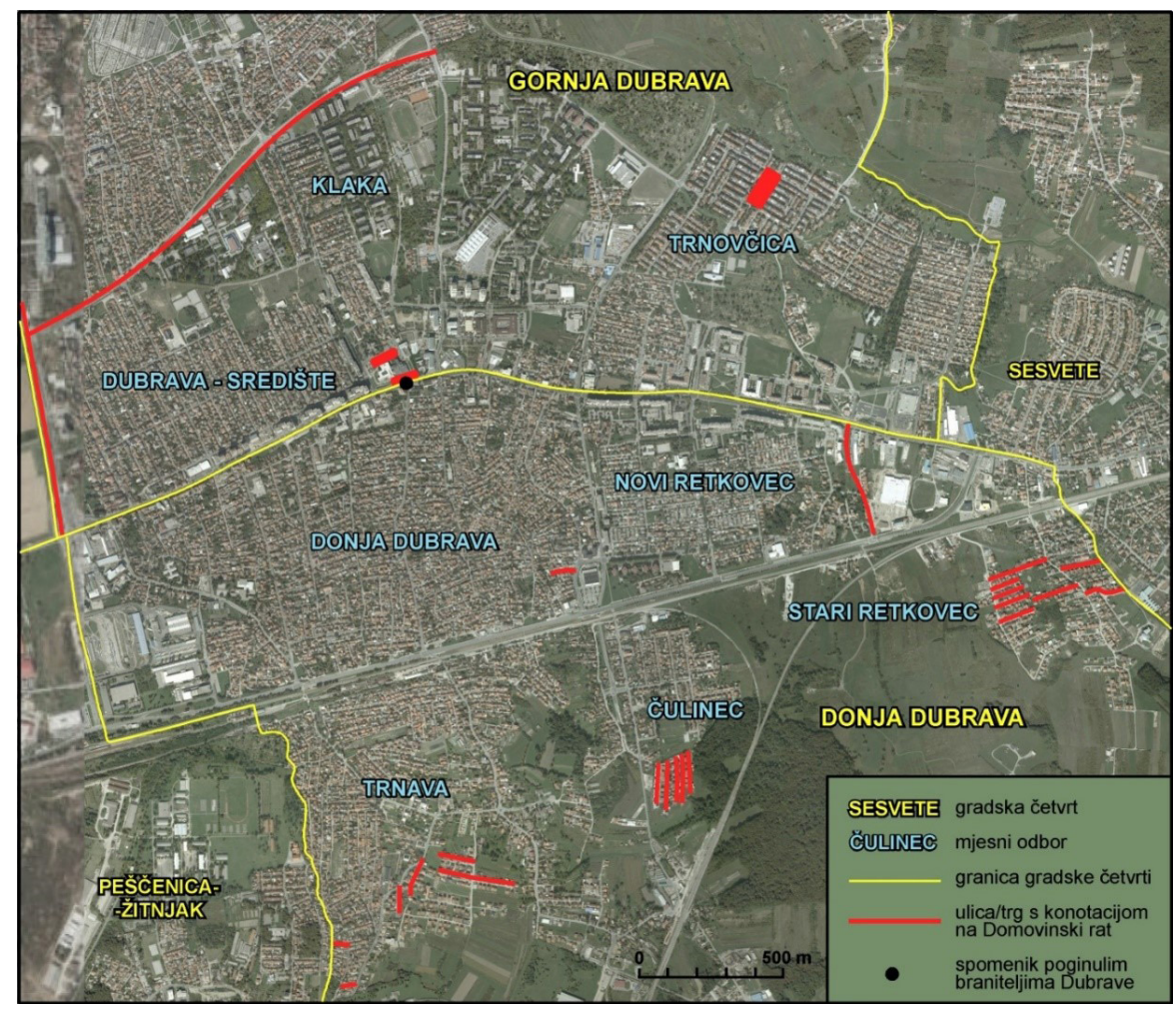

Slika 6. Ulice imenovane 200I. - 2016. koje komemoriraju Domovinski rat. Izvor: Službeni glasnik Grada Zagreba 200I. 2016.; Zg Geoportal; izradila: Ivana Crljenko, 2017. godine

Epideiktička retorika, koja odvaja "vrlinu i moralno nevaljalstvo, lijepo i ružno" (Aristotel 1989: 39), obilježila je sukob diskursa oko Avenije Gojka Šuška, nazvane 1998. godine po ratnome ministru obrane. Anonimnom akcijom 2006. godine ulične ploče s tim imenom po cijeloj dužini ulice bile su oblijepljene natpisom "Ulica grada Den Haaga”. Anonimni su se počinitelji očito referirali na Međunarodni sud za ratne zločine na području bivše Jugoslavije, poznat kao Haški tribunal. Pokretane su i inicijative za preimenovanjem avenije, s obrazloženjem da su i svjedoci tijekom suđenja na Haškom tribunalu povezivali Šuška s "prikrivanjem ratnih zločina” i "događajima koji su rezultirali uspostavljanjem koncentracijskih logora u BiH” (Špoljar

\footnotetext{
${ }^{33} \operatorname{Trg} 145$. brigade.

${ }^{34}$ Park poginulih dragovoljaca Trnovčice i Park dubravskih branitelja.
} 
i Kovačević 2010). Do preimenovanja nije došlo, dijelom zbog snažnoga otpora braniteljskih udruga, koji su inicijativu doživjeli kao "napad na dignitet Domovinskog rata i hrvatske branitelje općenito” (prema Brkulj 2010; Zrinjski 2010; s. n. 2010).

Dakle, gradski tekst Dubrave, kao složen znakovni sustav, materijalizirao je i fiksirao mnoge procese društvenoga sukobljavanja i pregovaranja oko pitanja ideologije i prošlosti. Postsocijalistička promjena njegove semantike nije bila potpuna i radikalna. Stoga je u njemu i danas otisnuta društvena polifonija i cijeli raster društvenih odnosa - od ideološke konfrontacije, netrpeljivosti i isključivanja do dopuštanja, uvažavanja i tolerancije.

\section{Promjena geografije u imenima ulica}

Preimenovanjima nakon 1991. sustav uličnoga nazivlja Dubrave još se više "geografizirao”. I ranije su, kao što je već spomenuto, mnoga imena ulica bila motivirana toponimima - lokalnim, hrvatskim i jugoslavenskim. Deideologizacijom uličnoga nazivlja broj takvih ulica porastao je u segmentu lokalne (pučke) i hrvatske toponimije, a niti jedna ulica, posve očekivano, nije preimenovana prema toponimima iz bivše Jugoslavije koji nisu povezani s hrvatskim identitetom (vidi Sliku 1). Dakle, mahom se radilo o hrvatskim toponimima, a nekoliko je novih ulica uključilo i toponime iz $\mathrm{BiH},{ }^{35}$ ponajviše iz Hercegovine. Uglavnom je riječ o imenima manjih naselja iz različitih hrvatskih područja - Karlovačke, Šibenske, Virovitičke, Zadarske regije te otoka Cresa, Lošinja, Paga. Zastupljena je i Slavonija: 11\% preimenovanih ulica dobilo je ime po slavonskim naseljima, i to potkraj 1992. i početkom 1993. godine, u jeku Domovinskoga rata. Naime, u razdoblju kada su mnogi prognanici iz ratom razorenih dijelova Istočne Slavonije bili udomljeni u Dubravi, ${ }^{36}$ ondje se niz ulica imenuje po slavonskim naseljima iz područja odakle je dolazio val prognanika, ${ }^{37}$ pa se tako fenomen migracija (ovaj put prisilnih) ponovno očituje u Dubravi na dva načina - u zbilji i u simboličkoj strukturi.

Promjena geografije dubravskih ulica događala se i preko nestanka mnogih imena koja su uključivala toponime bivše Jugoslavije. Usporedbom imena ulica iz plana grada iz 1984. s današnjim stanjem uočava se da su nestali hodonimi Ibarska ulica, Zlatiborska, Crnogorska, Pirotska, Jagodinska i neki drugi (Slika 7). Ipak, niz imena iste ili slične motivacije ostao je nepromijenjen. Radi se o ulicama nazvanima po manjim industrijskim, rudarskim ili turističkim mjestima, ${ }^{38}$ ali i po rijekama i planinama $^{39}$ bivše Jugoslavije. Dakle, u Dubravi proces preimenovanja 1990-ih nije bio radikalan te nije zahvatio sve ulice nazvane po tada neprijateljskim područjima bivše

\footnotetext{
${ }^{35}$ Međugorska, Visočička, Kupreška, Lašvanska, Vareška.

${ }^{36}$ Samo iz Vukovara u Dubravi je u to vrijeme živjelo oko 700 prognanika (Švob, Brčić i Podgorelec 1998: 23).

${ }^{37}$ Sarvaška, Bogdanovačka, Sotinska, Ivankovačka, Jarminska, Nemetinska, Cerićka, Aljmaški put, Ćelijski put. Ulice su bili smještene u blizini već otprije postojećih "slavonskih" ulica - Osječke, Vukovarske, Mikanovačke i dr.

${ }^{38}$ Kao periferno područje, Dubrava je u svojim ulicama reproducirala mala i manje poznata naselja (npr. Dobropoljska, Banovićka, Virovska, Prijepoljska ulica i dr.).

${ }^{39}$ Na primjer, Timočka, Mlavska, Ibarska, Motajička, Treskavička, Tušnička ulica.
} 
države. Takva imena ulica očito nisu bila provokativna ili konotativna pa su stoga preživjela intenzivni val postsocijalističkih preimenovanja.

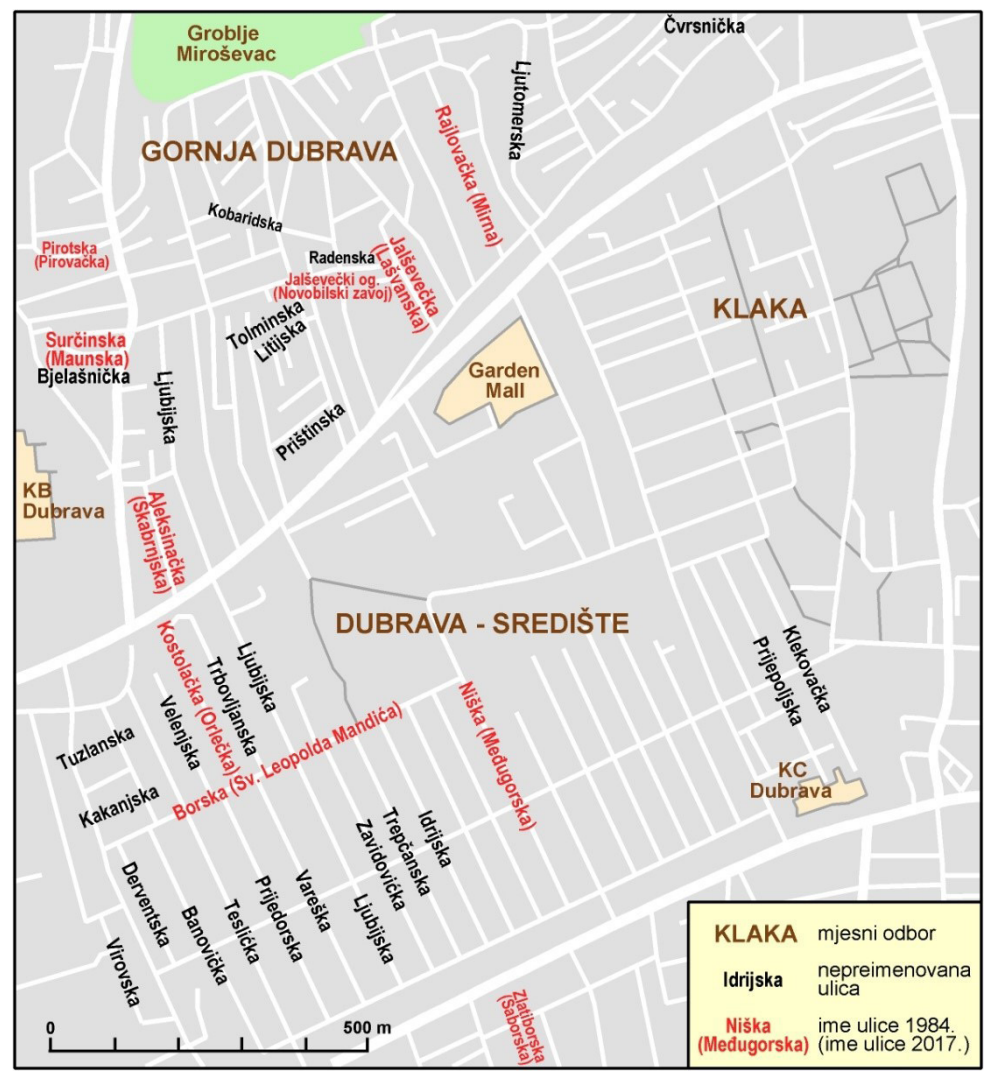

Slika 7. Jugoslavenska toponimija u užoj Dubravi 1984. i 2017. godine. Izvor: Popis preimenovanih ulica i trgova, 2007.; Službeni glasnik Grada Zagreba 2007. - 2016.; Službene stranice Grada Zagreba; Zagreb - plan grada sa svim općinama, 1984.; lg Geoportal; Google Maps; izradila: Ivana Crljenko, 2017. godine

\section{Sakralizacija krajolika}

U europskim gradovima sfera sakralnoga tradicionalno je prisutna u imenima ulica. U socijalističkim društvima taj je element gotovo potpuno bio odsutan. Kao što vidimo iz plana grada iz 1990., u Zagrebu su te godine samo tri ulice imale religijske konotacije - Svetoivanjska na Trešnjevci, Šimunska ${ }^{40} \mathrm{u}$ Maksimiru i Ulica Marije Snježne u Dubravi. U valu preimenovanja ulica do 2007. godine broj takvih ulica već je narastao iznad trideset. Šesnaest je od njih u Dubravi, pa tu doista možemo govoriti o visokoj koncentraciji ulica sakralnoga sadržaja u odnosu na ukupni pro-

\footnotetext{
${ }^{40}$ Kasnije preimenovana u Svetošimunsku.
} 
stor Zagreba. Toj koncentraciji odgovara i relativno obilje religijske "infrastrukture": desetak crkava i tri samostana, jedan vjerski spomenik ${ }^{41}$ te mnogobrojna raspela i kapelice.

Relativnu mnogobrojnost sakralnih elemenata u Dubravi možemo objasniti dvama čimbenicima: crkvenom tradicijom starih dubravskih sela i priljevom migranata Hrvata (osobito iz $\mathrm{BiH}$ is Kosova) sa snažno izraženim vjerskim identitetom.

Prva župna crkva Blažene Djevice Marije u Čučerju spominje se 1334. godine, a stara crkva u Granešini, poslije uništena u potresu, postojala je već 1266 . godine. Do druge polovice 19. stoljeća u Dubravi su se nalazile čučerska crkva Pohoda Marijina i granešinska crkva Rođenja Blažene Djevice Marije, kao sjedišta župa. Smještene na istaknutim, najbolje pozicioniranim dijelovima naselja, crkve su bile vidljive te su služile kao orijentiri, kao mjesta okupljanja stanovnika i središta društvenoga života. Kontinuitet brige o crkvama, stalna nadogradnja, obnavljanje okoliša nedvojbeno upućuju na istaknutu tradicionalnu društvenu ulogu Crkve u starim selima Gornje Dubrave. Do sredine 20. stoljeća Dubrava dobiva još nekoliko vjerskih objekata, uključujući i prvu crkvu na području Donje Dubrave s kapucinskim samostanom svetog Mihaela. Nakon pedeset godina zastoja u crkvenoj gradnji, početkom 1990-ih nastaje pravi boom crkvenoga graditeljstva. U Dubravi je od 1992. do 2010. godine izgrađeno sedam modernih crkava te franjevački ${ }^{42}$ i drugi zagrebački kapucinski sa$\operatorname{mostan}^{43}$ (Crljenko 2011: 288).

U skladu s očuvanom tradicijom starih sela, kulturni krajolik Gornje Dubrave obiluje malim sakralnim objektima - kapelicama i raspelima. Dvadesetak raspela podignuto je samo u župi Čučerje, od toga petnaest novih. U svrhu dostupnosti i vidljivosti najčešće se lociraju na raskrižjima cesta ili uz prometnice, putove, puteljke (Crljenko 2011: 290). Budući da su takvi elementi krajolika u načelu svojstveni ruralnim sredinama, njihova naglašena prisutnost dobro indicira očuvanje ruralne tradicije, zadržavanje ruralnih obilježja u uvjetima uključenosti u urbano tkivo Zagreba, dvojni ruralno-urbani identitet.

Godine 1991. u Čučerju je izgrađen i vjerski spomenik. Kip Bogorodice u pozlaćenoj bronci podignut je povodom 790 godina prvoga zapisa o Marijinom Čučerju (vidi Sliku 3B). Postavljen je na glavnom čučerskom trgu, na mjestu premještenog spomenika palim borcima Čučerja, uključivši se tako u postsocijalističku resemiotizaciju prostora.

Sakralnoj naglašenosti u Dubravi znatno su pridonijeli Hrvati doseljeni iz drugih dijelova bivše Jugoslavije, u prvome redu iz Bosne i Hercegovine te s Kosova. Podaci popisa pokazuju da je u Dubravi 2011. godine živjelo 11080 stanovnika doseljenih iz BiH i 3614 s Kosova. ${ }^{44}$ Premda nema točnih statističkih podataka o njihovoj prostornoj distribuciji, dubravsko stanovništvo poistovjećuje Trnovčicu s Hercegovcima, Dubec i Retkovec s Posavcima, Konjščinsku i okolne ulice s Janjevcima. Hrvati

\footnotetext{
${ }^{41}$ Spomenuti kip Bogorodice na Trgu sv. Marije Čučerske u Čučerju.

${ }^{42}$ Hercegovačkoga provincijala.

${ }^{43}$ Sv. Leopolda Mandića.

${ }^{44}$ Treba imati na umu da u taj broj ulaze sve etničke skupine doseljene iz tih zemalja, iako možemo pretpostaviti da se u prvome redu radi o Hrvatima.
} 
migranti, doseljeni iz religijski mješovitih sredina, povezivanjem s Crkvom potvrđuju svoj nacionalni i katolički identitet. Stoga crkva za njih ima visok aksiološki status. Povezivanje identiteta migrantskih zajednica s Katoličkom Crkvom otisnuto je u "sakralizaciji" dubravskoga krajolika. Zanimljiv slučaj vidimo u sjevernom dijelu Dubrave naseljenom Hercegovcima (Brčić i Čaldarović 1998: 68). Čak osam ulica mjesnoga odbora Trnovčica nazvano je po svećenicima iz $\mathrm{BiH}$, većinom franjevcima iz Hercegovine. ${ }^{45}$ Tako su ulice Trnovčice na vrlo osebujan način označile identitet njezinih novih stanovnika povezujući ga s Crkvom i Domovinom - religijom i zavičajem.

\section{Zaključak}

Gradski tekst Dubrave ima razlikovne karakteristike koje možemo povezati s perifernom pozicijom u gradu.

Kratko razdoblje urbane povijesti Dubrave očitovalo se u mnoštvu elemenata ruralnoga podrijetla $-\mathrm{u}$ imenima ulica mnogo je patronima, imena bratovština, imena starih sela. Krajolik Dubrave obilježavaju brojni elementi ruralne tradicije - kapelice, raspela.

Periferni položaj uzrokovao je širenje teritorija, formiranje novih ulica, niske cijene zemljišta, pa tako privlačnost i pogodnost Dubrave za naseljavanje migranata. Prisutnost migranata vidljiva je u brojnosti geografskih toponima u uličnom nazivlju. Sastav dubravskih doseljenika u prošlom režimu pretočio se u obilje ulica s toponimima iz Srbije, BiH i drugih dijelova Jugoslavije. Dolazak migranata Hrvata iz religijski mješovitih sredina, gdje je njihov identitet tradicionalno vezan uz Katoličku Crkvu, očitovao se tijekom i nakon Domovinskog rata u simboličkoj "sakralizaciji" krajolika.

Zbog svojega perifernoga položaja, Dubrava nikada nije bila središtem ideoloških interesa, kao što je to bilo središte Zagreba, što se očitovalo u hodonimskom i spomeničkom obilježavanju fenomena uglavnom tek od lokalnog značenja lokalnih događaja, lokalnih stanovnika. Hodonimi, nazvani u prošlom režimu po jugoslavenskim toponimima, reproducirali su u prvome redu imena malih naselja ili prirodna obilježja (rijeke, planine). Zbog neprovokativnosti i "nevidljivosti” takvoga gradskoga teksta u širom kontekstu Zagreba postsocijalističko "brisanje" diskursa bratstva i jedinstva u Dubravi je imalo blaže, manje radikalne oblike.

Stvaranje novih ulica na periferiji odredila je mogućnost veličanja i obilježavanja suvremenih događaja, odnosno događaja iz bliske prošlosti. U skladu s takvom epideiktičkom retorikom, u dubravski gradski tekst znakovno je bio ugrađen Domovinski rat.

\footnotetext{
${ }^{45}$ Ulica Petra Bakule, Anđela Nuića, Jurja Dragišića, Julijana Jelenića, Franje Milićevića, Rafe Barišića, Josipa Stadlera, Izidora Poljaka.
} 
Dakle, možemo zaključiti da je periferni položaj Dubrave na mnoge načine odredio semantiku njezina gradskoga teksta.

U gradskom tekstu Dubrave očitovale su se, naravno, i opće tendencije. On nam još jednom ukazuje na "promjenu referencijalnoga okvira koji se događa kada povijesno ime postaje prostorna destinacija” (Azaryahu 1996: 322). Istraživanje dubravskoga gradskoga teksta, nadamo se, još je jednom pokazalo mogućnosti koje semiotički pristup daje u iščitavanju višestrukih osi identiteta i moći te načina na koji se oni transponiraju u prostor.

\section{LITERATURA}

Alderman, Derek. 2000. "A Street Fit for a King. Naming Places and Commemoration in the American South". Professional Geographer 52/4: 672-684. [https://doi.org/10.1111/0033-0124.00256]

Alderman, Derek. 2002. "Street Names as Memorial Arenas. The Reputational Politics of Commemorating Martin Luther King Jr. in a Georgia County”. Historical Geography 30: 99-120.

Alderman, Derek. 2003. "Street Names and the Scaling of Memory. The Politics of Commemorating Martin Luther King, Jr. within the African American Community”. Area 35/2: 163-173. [https://doi.org/10.1111/14754762.00250]

Alderman, Derek. 2010. “Surrogation and the Politics of Remembering Slavery in Savannah, Georgia (USA)”. Journal of Historical Geography 36/1: 90-101. [https://doi.org/10.1016/j.jhg.2009.08.001]

Aristotel. 1989. Retorika. Zagreb: Naprijed.

Atkinson, David i Denis Cosgrove. 1998. "Urban Rhetoric and Embodied Identities. City, Nation and Empire at the Vittorio Emanuele II Monument in Rome, 1870-1945”. Annals of the Association of American Geographers 88: 28-49.

Azaryahu, Maoz. 1996. "The Power of Commemorative Street Names”. Environment and Planning D: Society and Space 14/3: 311-330. [https://doi.org/10.1068/d140311]

Azaryahu, Maoz. 1997. "German Reunification and the Politics of Street Names. The Case of East Berlin". Political Geography 16/6: 479-493. [https://doi.org/10.1016/S0962-6298(96)00053-4]

Azaryahu, Maoz i Rebecca Kook. 2002. "Mapping the Nation. Street Names and Arab-Palestinian Identity: Three Case Studies”. Nations and Nationalism 8/2: 195-213.

Azaryahu, Maoz. 2003. "RePlacing Memory. The Reorientation of Buchenwald". Cultural Geographies 10: 1-20. [https://doi.org/10.1191/1474474003eu265oa]

Azaryahu, Maoz i Kenneth Foote. 2008. "Historical Space as Narrative Medium. On the Configuration of Spatial Narratives of Time at Historical Sites”. GeoJournal 73/3: 179-194.

Azaryahu, Maoz. 2012. "Renaming the Past in Post-Nazi Germany. Insights into the Politics of Street Naming in Mannheim and Potsdam”. Cultural Geographies 19/3: 385-400. [https://doi.org/10.1177/1474474011427267]

Begonja, Zlatko. 2006. “Odonimi kao ideološke manifestacije na primjeru Zadra u XX. stoljeću”. Radovi Zavoda za povijesne znanosti HAZU u Zadru 48: 703-720.

Berg, Lawrence i Robin Kearns. 1996. "Naming as Norming. 'Race,' Gender, and the Identity Politics of Naming Places in Aotearoa/New Zealand”. Environment and Planning D: Society and Space 14/1: 99-122.

Brčić, Carmen i Ognjen Čaldarović. 1998. "Položaj mladih u Dubravi (Zagreb). Socijalna integracija i dezintegracija”. Migracijske teme 14/1-2: 65-77.

Brkulj, V. 2010. "Blokirat ćemo ulice ako promijene ime Avenije”. tportal online, 14. rujna. https://www.tportal.hr/ vijesti/clanak/blokirat-cemo-ulice-ako-promijene-ime-avenije-20100914/print (pristup 28. 3. 2017.).

Crljenko, Ivana. 2008. "Izraženost identiteta u gradskoj toponimiji kvarnerskih i istarskih gradova”. Hrvatski geografski glasnik 70/1: 67-90.

Crljenko, Ivana. 2011. Kulturni pejzaži zagrebačke Dubrave - tipološki pristup. Doktorska disertacija. Zagreb: Prirodoslovno-matematički fakultet Sveučilišta u Zagrebu.

Crljenko, Ivana. 2012a. “Utjecaj nekih sociogeografskih čimbenika na morfogenezu zagrebačke Dubrave”. Hrvatski geografski glasnik 74/1: 111-139.

Crljenko, Ivana. 2012b. "Migracijska i etnička obilježja stanovništva kao čimbenici promjene kulturnoga pejzaža zagrebačke Dubrave”. Migracijske i etničke teme 28/3: 287-315.

Czepczyński, Mariusz. 2008. Cultural Landscapes of Post-Socialist Cities. Representation of Powers and Needs. Hampshire: Ashgate. 
Dobrila-Pepo, Ante. 1986. Dubrava-Sesvete u NOR-u: 1941-1945. Zagreb: Općinski odbor SUBNORa Dubrava.

Duncan, James i Nancy Duncan. 1988. “(Re)reading the Landscape”. Environment and Planning D: Society and Space 6/2: $117-126$

Duncan, James. 1990. The City as Text. The Politics of Landscape Representation in the Kandyan Kingdom. Cambridge: Cambridge Iniversity Press.

Dwyer, Owen. 2004. "Symbolic Accretion and Commemoration". Social \& Cultural Geography 5/3: 419-435. [https://doi.org/10.1080/1464936042000252804]

Eco, Umberto. 1988. “An Ars Oblivionalis? Forget it!”. PMLA 103/3: 254-261. [https://doi.org/10.2307/462374]

Foote, Kenneth. 1997. Shadowed Ground. America's Landscapes of Violence and Tragedy. Austin: University of Texas Press.

Forest, Benjamin, Juliet Johnson i Karen Till. 2004. "Post-totalitarian National Identity. Public Memory in Germany and Russia”. Social \& Cultural Geography 5/3: 357-380. [https://doi.org/10.1080/1464936042000252778]

Globarević, Ilija. 1974. Socijalno-geografska problematika rubnih zona Zagreba na primjeru Dubrave. Magistarski rad. Zagreb: Prirodoslovno-matematički fakultet Sveučilišta u Zagrebu.

Grgin, Borislav. 2007. "Primjer selektivnog pamćenja. Hrvatski srednjovjekovni vladari u nazivlju ulica i trgova najvažnijih hrvatskih gradova”. Povijesni prilozi 32: 283-295.

Hook, Derek. 2005. "Monumental Space and the Uncanny". Geoforum 36: 688-704. [https://doi.org/10.1016/j. geoforum.2004.11.009]

Hrženjak, Juraj, ur. 2002. Rušenje antifašističkih spomenika u Hrvatskoj 1990-2000. Zagreb: Savez antifašističkih boraca Hrvatske.

Ivanuša, Dolores. 1981. “Memorijalni muzej Pete zemaljske konferencije KPJ”. Informatica museologica 11/4: 37-44.

Johnson, Nuala. 1995. “Cast in Stone. Monuments, Geography and Nationalism”. Environment and Planning D: Society and Space 13/1: 51-65. [https://doi.org/10.1068/d130051]

Johnson, Nuala. 2004. "Public Memory”. U A Companion to Cultural Geography. James S. Duncan, Nuala C. Johnson i Richard H. Schein, ur. Oxford: Blackwell Publishing, 316-327. [https://doi.org/10.1002/9780470996515. ch21]

Junaković, Magda. 1978. “Zapisi o Dubravi (2)”. Dubrava - list radnih ljudi i građana općine Dubrava-Zagreb. Zagreb, 1, 14.

Kožarić, Ivan, ur. 2007. Spomenici i fontane u gradu Zagrebu. Vodič. Zagreb: Hrvatska akademija znanosti i umjetnosti, Gliptoteka, Grad Zagreb, Gradski zavod za zaštitu spomenika kulture i prirode.

Lachmann, Renate. 2002. Phantasia / Memoria / Rhetorica. Zagreb: Matica hrvatska.

Ladović, Vanda. 1960. “Pregled razvoja Zagrebačke Dubrave”. U Iz starog i novog Zagreba, 2. Franjo Buntak i dr., ur. Zagreb: Muzej grada Zagreba, 299-310.

Legg, Stephen. 2007. "Reviewing Geographies of Memory/Forgetting”. Environment and Planning A 39/2: 456466. [https://doi.org/10.1068/a38170]

Light, Duncan, Ion Nicolae i Bogdan Suditu. 2002. "Toponymy and the Communist City. Street Names in Bucharest, 1948-1965”. GeoJournal 56/2: 135-144. [https://doi.org/10.1023/A:1022469601470]

Light, Duncan. 2004. "Street Names in Bucharest, 1990-1997. Exploring the Modern Historical Geographies of Post-Socialist Change”. Journal of Historical Geography 30/1: 154-172. [https://doi.org/10.1016/S03057488(02)00102-0]

Light, Duncan i Craig Young. 2014. "Habit, Memory, and the Persistence of Socialist-Era Street Names in Postsocialist Bucharest, Romania”. Annals of the Association of American Geographers 104/3: 668-685.

Lotman, Yuri. 1992. Izbrannye stat'i $v$ trekh tomakh, 1. Tallin: Aleksandra.

Lotman, Yuri. 1993. Izbrannye stat'i v trekh tomakh, 3. Tallin: Aleksandra.

Lowenthal, David. 1979. "Age and Artifact. Dilemmas and Appreciation”. U The Interpretation of Ordinary Landscapes. Geographical Essays. Donald W. Meinig, ur. New York, Oxford: Oxford University Press: 103-128.

Mac Aodha, Breandán. 1989. "The History and Nature of Irish Street Names”. Names 37: 345-365. [https://doi. org/10.1179/nam.1989.37.4.345]

Marjanović, Bojan. 2007. “Promjena vlasti, promjena ulica”. Diskrepancija 8/12: 105-127.

Mataija, Ivica. 2014. "Gospićka hodonimija”. Folia onomastica Croatica 23: 143-158.

Meinig, Donald. 1979. “Introduction”. U The Interpretation of Ordinary Landscapes. Geographical Essays. Donald W. Meinig, ur. New York, Oxford: Oxford University Press, 1-7.

Mirošević, Lena i Marin Borzić. 2014. “Ulična nomenklatura grada Splita kao odraz političkih i kulturnih promjena”. Etnološka tribina 37: 187-201. [https://doi.org/10.15378/1848-9540.2014.37.07]

Mirošević, Lena. 2016. “Street and Square Names as Reflections of Cultural and Historical Heritage”. Kartografija $i$ Geoinformacije 16: 56-71.

Myers, Garth. 1995. "Naming and Placing the Other. Power and Urban Landscape in Zanzibar". Tijdschrift voor Economische en Sociale Geografie 87: 237-246. [https://doi.org/10.1111/j.1467-9663.1998.tb01553.x]

Oroz, Tomislav i Nevena Škrbić Alempijević. 2015. "Dva lica spomenika. Politike i prakse korištenje Spomenika Seljačkoj buni i Matiji Gupcu u Gornjoj Stubici”. Studia ethnologica Croatica 27: 131-187. 
Palonen, Emilia. 2008. “The City-Text in Post-Communist Budapest. Street Names, Memorials, and the Politics of Commemoration”. GeoJournal 73: 219-230. [https://doi.org/10.1007/s10708-008-9204-2]

Palonen, Kari. 1993. "Reading Street Names Politically”. U Reading the Political. Kari Palonen i Tuija Parvikko, ur. Tampere: The Finnish Political Science Association, 103-121.

Pinchevski, Amit i Efraim Torgovnik. 2002. "Signifying Passages. The Signs of Change in Israeli Street Name". Media, Culture \& Society 24: 365-388.

Radović, Srđan. 2014. "Politike simbola na gradskim ulicama. Obrasci preimenovanja javnih prostora u postjugoslovenskim zemljama”. Narodna umjetnost 51/2: 117-132. [https://doi.org/10.15176/vol51no206]

Radović, Srđan. 2016. "Grad, ulice i krajolici kao teme etnoantropološkog istraživanja nakon Ulica moga grada”. Narodna umjetnost 53/2: 79-96. [https://doi.org/10.15176/vol53no205]

Rihtman-Auguštin, Dunja. 2000. Ulice moga grada. Beograd: Biblioteka XX vek.

Robinson, Guy i Alma Pobrić. 2006. "Nationalism and Identity in Post-Dayton Accords: Bosnia-Herzegovina”. Tijdschrift voor Economische en Sociale Geografie 97: 237-252.

Rose-Redwood, Reuben. 2008. "Sixth Avenue is Now a Memory. Regimes of Spatial Inscription and the Performative Limits of the Official City-Text”. Political Geography 27/8: 875-894. [https://doi.org/10.1016/j.polgeo.2008.11.002]

Rose-Redwood, Reuben, Derek Alderman i Maoz Azaryahu. 2010. "Geographies of Toponymic Inscription. New Directions in Critical Place-Name Studies”. Progress in Human Geography 34/4: 453-470. [https://doi. org/10.1177/0309132509351042]

Rose-Redwood, Reuben, Derek Alderman i Maoz Azaryahu, ur. 2017. The Political Life of Urban Streetscapes. Naming, Politics and Place. London: Routledge.

Sidaway, James i Peter Mayell. 2007. "Monumental Geographies. Re-situating the State”. Cultural Geographies 14: 148-155.

[s. n.] 2010. “Zagrebačka HVIDR-a protiv promjene imena Avenije Gojka Šuška”. Monitor.hr, 14. rujna. http:// www.monitor.hr/clanci/zagrebacka-hvidr-a-protiv-promjene-imena-avenije-gojka-suska/38750/ (pristup 28. 3. 2017.).

Stanić, Jelena, Laura Šakaja i Lana Slavuj. 2009. "Preimenovanja zagrebačkih ulica i trgova”. Migracijske i etničke teme 25: 89-124.

Šakaja, Laura i Stanić, Jelena. 2011. “Other(ing), Self(potraying), Negotiating. The Spatial Codification of Values in Zagreb’s City-Text”. Cultural Geographies 18/4: 495-516. [https://doi.org/10.1177/1474474011414636]

Šakaja, Laura. 2015. Uvod u kulturnu geografiju. Zagreb: Leykam international.

Šimunović, Petar. 1970. “O pisanju naziva zagrebačkih ulica”. Jezik 18/1: 14-27.

Špoljar, Marko i Jelena Kovačević. 2010. “Pokojni ministar obrane Gojko Šušak ostaje bez svoje avenije”. Večernji list online, 13. travnja. https://www.vecernji.hr/regije/pokojni-ministar-obrane-gojko-susak-ostaje-bez-svojeavenije-clanak-125489 (pristup 27.4. 2017.).

Švob, Melita, Carmen Brčić i Sonja Podgorelec. 1998. “Mladi u Dubravi”. Migracijske teme 14/1-2: 7-32.

Till, Karen. 1999. “Staging the Past. Landscape Designs, Cultural Identity and Erinnerungspolitik at Berlin's Neue Wache”. Ecumene 6: 251-283. [https://doi.org/10.1191/096746099701556277]

Ugarković, Stipe i Ivan Očak. 1979. Zagreb grad heroj. Spomen-obilježja revoluciji. Zagreb: August Cesarec.

Vretenar, Katja i Zlatan Krajina. 2016. "Politike označavanja i patrijarhalna konstrukcija Zagreba”. Politička misao 53/3: 50-81.

Vuolteenaho, Jani i Lawrence Berg. 2009. “Towards Critical Toponymies”. U Critical Toponymies. The Contested Politics of Place Naming. Lawrence D. Berg i Jani Vuolteenaho, ur. Burlington: Ashgate, 1-18.

Yeoh, Brenda. 1992. "Street Names in Colonial Singapore". Geographical Review 82/3: 313-322. [https://doi. org/10.2307/215354]

Yeoh, Brenda. 1996. "Street Naming and Nation-building. Toponymic Inscriptions of Nationhood in Singapore". Area 28/3: 298-307.

Withers, Charles. 2000. “Authorizing Landscape. 'Authority', Naming and the Ordnance Survey's Mapping of the Scottish Highlands in the Nineteenth Century”. Journal of Historical Geography 26: 532-554. [https://doi. org/10.1006/jhge.2000.0244]

Zrinjski, Marijana. 2010. "Ako ratnom ministru Šušku uzmu ulicu - štrajk glađu i blokada”. Večernji list online, 14. rujna. https://www.vecernji.hr/zg-vijesti/ako-ratnom-ministru-susku-uzmu-ulicu-strajk-gladju-i-blokada-190973 (pristup 28. 3. 2017.).

\section{Planovi grada:}

Zagreb. Popis ulica i plan grada. Zagreb: Epoha, 1959.

Zagreb - popis ulica i plan grada. Zagreb: Geodetski zavod grada Zagreba, 1965.

Zagreb - plan grada sa svim općinama (ur. V. Kipčić). Zagreb: Grafički zavod Hrvatske, 1984.

Zagreb. Plan Grada. Zagreb: Grafički zavod Hrvatske, 1990. 


\section{Popisi i dokumentacija:}

Dokument Gradskog ureda za graditeljstvo, stambene i komunalne poslove, promet $i$ veze. Zagreb, 2000.

Obavijest o stanju spomenika i spomen obilježja na području PU Trešnjevka. Gradski sekretarijat za obrazovanje, kulturu i znanost, Zagreb, 1992.

Popis preimenovanih ulica i trgova. Ured za katastar i geodetske poslove grada Zagreba, Zagreb, 2007.

Popis skulptura i spomen ploča. Gradski zavod za zaštitu spomenika kulture i prirode, Zagreb, 1999.

Popis spomen-obilježja i spomenika antifašističke borbe na području Grada Zagreba koje je Gradski zavod za zaštitu spomenika kulture i prirode tijekom 1990.-2000. god. imao u postupku uklanjanja, odnosno izvršio uviđaj zbog oštećenja. Gradski zavod za zaštitu spomenika kulture i prirode, Zagreb, 2001.

\section{Mrežni izvori:}

Google Maps. https://www.google.hr/maps?source=tldso (pristup 15. 2. 2017.).

Popis stanovništva 2001. i 2011. Državni zavod za statistiku, http://www.dzs.hr (pristup 21. 2. 2017.).

Službene stranice Grada Zagreba. Zagreb.hr, http://www.zagreb.hr/default.aspx (pristup 20. 2. 2017.).

Službeni glasnik Grada Zagreba (2001. - 2016.). Službeni glasnik Grada Zagreba, http://www1.zagreb.hr/slglasnik/ index.html\#/home (pristup 3. 2. 2017.).

$\mathrm{Zg}$ Geoportal. Geoportal zagrebačke infrastrukture prostornih podataka. https://geoportal.zagreb.hr (pristup 10. 5. 2017.).

\section{Peripheral City-Text. Street Names and Monuments in Dubrava (Zagreb) - a Semiotic Perspective}

In a semiotic sense, the city-text is a symbolic structure with complex social and communicative functions and codes that enable communication between the sender and the recipient of the message, i.e. between the public and its cultural tradition. The textual interpretation of all street names and monuments in a certain area is based on the common characteristics of the city and the written text: these are symbolic entities with fixed, i.e. objectified meanings; they represent the contexts in which they originated, and they are subject to different interpretations. This article explores the ways in which ideology is interwoven into the spatial-symbolic landscapes of the city. The city's periphery, in this case Dubrava - which has a special axiological-symbolic organization - forms an opposition with the city centre (as the "most visible space").

Keywords: city-text, urban toponymy, street names, monuments, Dubrava (Zagreb) 